\title{
Oral Health in the Family Health Strategy: analysis of articles published in the period 2004-2014
}

\author{
Saúde bucal na Estratégia de Saúde da Família: \\ análise dos artigos publicados no período 2004-2014
}

Chaiane Emilia Dalazen ${ }^{1}$

Alessandro Diogo De-Carli ${ }^{1}$

Samuel Jorje Moyses ${ }^{2}$

${ }^{1}$ Universidade Federal de Mato Grosso do Sul. Cidade Universitária, Pioneiros. 79070-900 Campo Grande MS Brasil.

chaianeed@gmail.com

2 Pontifícia Universidade Católica do Paraná. Curitiba PR Brasil.

\begin{abstract}
This study aimed to conduct an integrative review of scientific literature on the topic of Oral Healt $\backslash h$ in the Family Health Strategy in the period 2004-2014. Articles published in national and international journals $(n=141)$ were consulted and selected from the electronic Library the Scientific Electronic Library Online (SciELO) and from electronic databases PubMed, Lilacs, BBO and Cochrane. The implementation process of oral health teams in the Family Health Strategy was the most frequent thematic variable (18\%) of the 15 variables identified. The Northeast was the Brazilian macro-region where the largest number of published articles originated $(n=61)$. The studies were predominantly quantitative, and the highest number of publications occurred in 2010 $(n=26)$. We concluded that there is an increasing interest in investigating the context of oral health implementation in the Family Health Strategy, with particular emphasis on theme categories related to the micro-process work and the redefinition of professional identities arising from multidisciplinary work in primary care.
\end{abstract}

Key words Scientific production, Family Health Strategy, Oral health, Primary Health Care
Resumo Este trabalho teve como objetivo realizar uma revisão integrativa da produção científica sobre o tema Saúde Bucal na Estratégia Saúde da Família, no período de 2004-2014. As fontes de consulta e seleção de artigos publicados em periódicos nacionais e internacionais $(n=141)$ foram a biblioteca eletrônica Scielo e as bases eletrônicas PubMed, Lilacs, BBO e Cochrane. O processo de implantação das equipes de Saúde Bucal na Estratégia de Saúde da Família foi a variável temática mais frequente (18\%) entre as 15 identificadas. A macrorregião brasileira onde se originou o maior número de artigos publicados foi a Nordeste ( $n=$ 61). Os estudos foram predominantemente quantitativos e o ano com o maior número de publicações foi $2010(n=26)$. Conclui-se que há um crescimento no interesse em se investigar o contexto de implantação da saúde bucal na ESF, com destaque particular para as categorias temáticas relacionadas ao microprocesso de trabalho e à redefinição de identidades profissionais decorrentes do trabatho multiprofissional na atenção primária.

Palavras-chave Produção científica, Estratégia Saúde da Família, Saúde bucal, Atenção Primária à Saúde 


\section{Introduction}

In 1994 the Family Health Strategy (FHS) was established as a entry point to care for users into the Unified Health System (SUS) in Brazil. The FHS teamwork in specific geographic areas and is responsible for implementing actions for health promotion, disease prevention, treatment of common health conditions and rehabilitation ${ }^{1,2}$.

The insertion of the Oral Health Team (OHT) into the Family Health Strategy (FHS) starting in 2000 represented the possibility of introducing a change into the current oral health care model of the national Unified Health System (UHS), which emphasizes dental care with a clinical, individual, repairing, and biomedical focus ${ }^{1}$. This transformation would be possible through conceptual redefinition and reorientation of practices aimed at actions based on the principles of integrity, coordination, and continuity of care by the OHT, among other strategic actions ${ }^{2}$.

Researchers have investigated the role of the OHT/FHS, particularly in aspects related to the micro-process work, innovation in care models, and potential epidemiological impact on oral health ${ }^{3-7}$. These studies' findings are important as they can influence future practices and investment in resources and serve as a basis for the development of other studies ${ }^{3,4}$. Thus, this review and comment on the scientific literature concerning the oral health topic in FHS allows more insight into the working process and the results of the recent integration/expansion of OHT in primary care in Brazil ${ }^{5,6}$.

One of the methodological possibilities to accomplish this task is an integrative review. This approach is widely accepted and used in international literature because it allows researchers to summarize information while providing a critical evaluation of the results of multiple primary studies regarding a certain topic ${ }^{8}$. Given the above, this work aims to conduct an integrative review of the scientific literature on oral health of the FHS during the period 2004-2014.

\section{Material and methods}

An integrative review study was conducted on published works addressing the issue of oral health in the Family Health Strategy. The search for articles was performed electronically in in the library Scientific Electronic Library Online (SciELO) and in the databases Public Medline (Pu-
bMed), Latin American and Caribbean Health Sciences Literature (Lilacs), Brazilian Dental Library (BBO) and Cochrane Library (Cochrane).

In the electronic library SciELO and in the databases Lilacs, BBO the following search terms were used: 'saúde da família and saúde bucal', 'odontologia em saúde pública and saúde da família', and 'odontologia and saúde da família', defined through consultation of Descritores em Ciências da Sáude (DeCS) (comparable to Medical Subject Headings - MeSH). In PubMed and Cochrane databases, the terms 'family health and oral health' and 'primary health care and oral health' were used, defined by the Medical Subject Headings (MeSH).

Only articles published in refereed journals were included in this integrative review, since they were subjected to the scrutiny of the editorial peer review process?.

The terms were searched in article titles, keywords, and abstracts. The inclusion criteria was articles from Brazil in English, Spanish, and Portuguese published in the period between 2004 and 2014. Only articles were selected; theses, dissertations and grey literature were excluded. When it was possible the inclusion criteria were adopt as searching filters for the articles according to the specificity of each database. The articles considered relevant were selected by reading the titles and abstracts. Three independent investigators read the titles and the abstracts and agreed that in case of disagreement over the inclusion or exclusion of any of the articles the divergence would be held to a vote.

To find and exclude duplicate articles, the reference manager EndNote X4 was used. After excluding duplicates, we selected those articles considered relevant to the review topic by reading the full texts. Three independent investigators read the full texts and agreed that in case of disagreement over the inclusion or exclusion of any of the articles, a new closed reading would be held, and the divergence remained would be held to a vote.

The collected information from the selected studies was processed using an instrument consisting of the following organizing elements: author, year of publication, title, journal of publication, location of the study, type of study, theme categories and the aims. The organizing elements were selected to facilitate the evaluation process. After extracting the information from the selected articles, results were analysed and discussed. 


\section{Results}

Initially, 6,803 publications were obtained: 5,607 in PubMed, 501 in Lilacs, 198 in BBO, 291 in the Cochrane database, and 206 in SciELO. After applying search filters appropriate in each database for the purpose, 451 studies considered relevant were selected. After reading the titles and abstracts, 271 duplicate articles and 39 theses and dissertations were excluded, resulting in 141 articles that met all the inclusion criteria. Reading of the articles text in full was done independently by two investigators and the data of the 141 articles was summarized by the integrative review meth$\operatorname{od}^{10}$. Chart 1 provides a list of selected studies. The flow diagram of articles selection is presented in Figure 1.

Chart 1. Author, Publication Year. Article title.

\begin{tabular}{|c|c|}
\hline Author, Publication Year. Article title & Author, Publication Year. Article title. \\
\hline $\begin{array}{l}\text { Pimentel et al., } 2012^{1} \text {. Characterization of the work } \\
\text { process by oral health teams in municipalities in } \\
\text { Pernambuco State, Brazil, according to population } \\
\text { size: from community links to organization of clinical } \\
\text { care. }\end{array}$ & $\begin{array}{l}\text { Melo et al., 2011. Accessibility to Oral Health Services } \\
\text { in Primary Care: Unveiling the Absenteeism in a } \\
\text { Family Health Unit of João Pessoa-PB. }\end{array}$ \\
\hline $\begin{array}{l}\text { Lenzi et al., 2010. Profile of the dentists members of } \\
\text { Family Health Program in a city in the South part of } \\
\text { Brazil. }\end{array}$ & $\begin{array}{l}\text { Sanglard 2013. Responsibilities of Oral Health } \\
\text { Technician in the Family Health Strategy in Minas } \\
\text { Gerais, Brazil. }\end{array}$ \\
\hline $\begin{array}{l}\text { Oliveira; Saliba, 2005. Dentistry attention in the } \\
\text { family's health program (FHP) in Campos dos } \\
\text { Goytacazes. }\end{array}$ & $\begin{array}{l}\text { Dovigo et al., 2011. Dental knowledge among } \\
\text { individuals from a family-health unit in São Carlos, } \\
\text { Brazil. }\end{array}$ \\
\hline $\begin{array}{l}\text { Costa et al., 2012. The dental assistant participation in } \\
\text { the public health team and the dental environment. }\end{array}$ & $\begin{array}{l}\text { Munkeviz; Pelicioni, 2010. Buccal Health In Family } \\
\text { Health Strategy In The City Of São Paulo: The } \\
\text { Patient's Perceptions. }\end{array}$ \\
\hline $\begin{array}{l}\text { Chaves; Miranda, 2008. Discourse among dentists } \\
\text { within the Family Healthcare Program: crisis and } \\
\text { change of habitus within public health. }\end{array}$ & $\begin{array}{l}\text { Almeida et al., 2010. Occurrence of dental caries and } \\
\text { associated factors in children from } 24 \text { to } 60 \text { months } \\
\text { living in areas covered by the Family Health Program, } \\
\text { Salvador - BA, } 2008 \text {. }\end{array}$ \\
\hline $\begin{array}{l}\text { Pinto et al., 2012. Emergency dental services in a } \\
\text { Health Unit linked to the Family Healthcare Strategy } \\
\text { of Montes Claros, Minas Gerais. }\end{array}$ & $\begin{array}{l}\text { Carnut; Figueiredo; Goés, 2011. Characterization of } \\
\text { dental health care in primary health through using } \\
\text { oral health form-D: preliminar results. }\end{array}$ \\
\hline $\begin{array}{l}\text { Rodrigues et al., 2010. Oral health team practices } \\
\text { within the family health strategy and construction } \\
\text { (de) construction of integrality in Feira de Santana- } \\
\text { BA. }\end{array}$ & $\begin{array}{l}\text { Nery et al., 2010. Satisfaction Levels of the Elderly } \\
\text { in Relation to Family Health Strategy, Through an } \\
\text { Analysis of Oral Health Care. }\end{array}$ \\
\hline $\begin{array}{l}\text { Santos et al., 2010. Affectivity as a tool in the adhesion } \\
\text { to guidelines on education in oral health in the Family } \\
\text { Health Program. }\end{array}$ & $\begin{array}{l}\text { Melo et al., 2010. Dental Caries in Preschoolers: A } \\
\text { Study in Areas Assisted by the Family Health Strategy } \\
\text { of the city of Recife, PE, Brazil. }\end{array}$ \\
\hline $\begin{array}{l}\text { Rodrigues; Bonfim, 2010. Oral health in the Family } \\
\text { Health Program of a municipality of the semi-arid } \\
\text { region of Bahia (Feira de Santana): organization and } \\
\text { micropolitics. }\end{array}$ & $\begin{array}{l}\text { Farias; Sampaio, 2010. Integrating Oral Health Team } \\
\text { At The Family Health Strategy: The Professionals' } \\
\text { Perception. }\end{array}$ \\
\hline $\begin{array}{l}\text { Villalba et al., 2009. Professional profile of dentist for } \\
\text { practice at Brazilian National Health System. }\end{array}$ & $\begin{array}{l}\text { Chaves; Cruz, 2012. Challenges for the organization of } \\
\text { Oral Health Care in Bahia, Brazil. }\end{array}$ \\
\hline $\begin{array}{l}\text { Martins et al., 2007. Profile of the dentists that } \\
\text { participate in the family health program of teresina } \\
\text { (PI). }\end{array}$ & $\begin{array}{l}\text { Nuto et al., 2010. The embracement of oral health } \\
\text { users in the Family Health Strategy, Fortaleza-CE: an } \\
\text { experience practice. }\end{array}$ \\
\hline $\begin{array}{l}\text { Medeiros; Freire, 2005. Implantation of the buccal } \\
\text { health to the strategy of family's health program in the } \\
\text { city of Bom Jesus do Norte-ES. }\end{array}$ & $\begin{array}{l}\text { Maia et al., 2005. Proposal of a protocol for thediabetic } \\
\text { patient dental attendance in basic health attention. }\end{array}$ \\
\hline
\end{tabular}


Chart 1. Author, Publication Year. Article title.

\begin{tabular}{|c|c|}
\hline Author, Publication Year. Article title & Author, Publication Year. Article title. \\
\hline $\begin{array}{l}\text { Bulgarelli et al., 2014. Resolubility in oral health for } \\
\text { primary care as an instrument for the evaluation of } \\
\text { health systems. }\end{array}$ & $\begin{array}{l}\text { Silva; Forte, 2009. Access to Dental Treatment, } \\
\text { Mother's Perception of Oral Health and Intervention } \\
\text { Strategies in the City of Mogeiro, PB, Brazil. }\end{array}$ \\
\hline $\begin{array}{l}\text { Pereira et al., 2012. Impact of the Family Health } \\
\text { Strategy: an analysis in cities in Northeast Brazil with } \\
\text { more than } 100,000 \text { inhabitants. }\end{array}$ & $\begin{array}{l}\text { Kitamura; Leite, 2009. Correlation between human } \\
\text { development Index and dental caries in a sample } \\
\text { of cities of minas gerais state: implications for the } \\
\text { inclusion of oral healthin the family health strategy. }\end{array}$ \\
\hline $\begin{array}{l}\text { Almeida et al., 2012. Family context and incidence } \\
\text { of dental caries in preschool children living in areas } \\
\text { covered by the Family Health Strategy in Salvador, } \\
\text { Bahia State, Brazil. }\end{array}$ & $\begin{array}{l}\text { Domingues et al., 2008. Oral health and dental care: } \\
\text { the social representations of mothers who attend a } \\
\text { public health service. }\end{array}$ \\
\hline $\begin{array}{l}\text { Bulgarelli et al., 2012. Primary healthcare and the } \\
\text { construction of meanings of oral health: a social } \\
\text { constructionist interpretation of discourses of the } \\
\text { elderly.. }\end{array}$ & $\begin{array}{l}\text { Melo; Rosa, 2009. Level of Knowledge and preventive } \\
\text { behavior of surgeon-dentists and users of basic } \\
\text { healthcare program in Aracaju-SE regarding Oral } \\
\text { Cancer. }\end{array}$ \\
\hline $\begin{array}{l}\text { Turrioni et al., 2012. Assessment of educational } \\
\text { actions on the oral health of adolescents within the } \\
\text { Family Health Strategy. }\end{array}$ & $\begin{array}{l}\text { Cruz et al., 2009. Working process in the family health } \\
\text { strategy: a perspective from the oral health team. }\end{array}$ \\
\hline $\begin{array}{l}\text { Baldani; Antunes, } 2011 \text {. Inequalities in access and } \\
\text { utilization of dental services: a cross-sectional study in } \\
\text { an area covered by the Family Health Strategy. }\end{array}$ & $\begin{array}{l}\text { Barbosa et al., 2007. Oral health care in the family } \\
\text { health program, from its implementation to today's } \\
\text { moment: Perceptions of dentists and assistants in } \\
\text { municipality context. }\end{array}$ \\
\hline $\begin{array}{l}\text { Stocco; Baldani, 2011. The control of babies' dental } \\
\text { visits through the vaccines card: evaluating a pilot } \\
\text { program developed at the Family Health Strategy at } \\
\text { Ponta Grossa (PR, Brazil). }\end{array}$ & $\begin{array}{l}\text { Pires et al., 2007. Knowledge of oral health by } \\
\text { community health agents: a perspective of educational } \\
\text { deficiencies in the family health program. }\end{array}$ \\
\hline $\begin{array}{l}\text { Ditterich et al., 2009. The work with family carried } \\
\text { through for academics of dentistry in the family } \\
\text { health strategy in Curitiba-PR: an experience practice. }\end{array}$ & $\begin{array}{l}\text { Cericato et al., 2010. A inserção do cirurgião-dentista } \\
\text { no PSF: uma revisão crítica sobre as ações e os } \\
\text { métodos de avaliação das Equipes de Saúde Bucal. }\end{array}$ \\
\hline $\begin{array}{l}\text { Oliveira et al., 2012. The community health agents and } \\
\text { oral cancer prevention. }\end{array}$ & $\begin{array}{l}\text { Medeiros et al., 2007. Dentist expectation about the } \\
\text { insertion of oral health in the family health program. }\end{array}$ \\
\hline $\begin{array}{l}\text { Carvalho et al., 2011. Dental pain in the previous } 3 \\
\text { months in adolescents and Family Health Strategy: } \\
\text { the comparison between two areas with different to } \\
\text { oralhealth care approaches }\end{array}$ & $\begin{array}{l}\text { Viana et al., 2012. Analysis of access to dental services } \\
\text { through the first dental programmatic appointment } \\
\text { indicator in Pernambuco: a comparative study } \\
\text { between the years } 2001 \text { and } 2009 .\end{array}$ \\
\hline $\begin{array}{l}\text { Soares et al., 2013. Inequalities in oral health care use } \\
\text { in the primary care setting and associated factors in } \\
\text { two Brazilian municipalities. }\end{array}$ & $\begin{array}{l}\text { Nascimento et al., 2013. Oral health in the context of } \\
\text { primary care in Brazil. }\end{array}$ \\
\hline $\begin{array}{l}\text { Silva et al., 2011. Analysis of the progress of the oral } \\
\text { health teams inserted in the Family Health Strategy } \\
\text { in Pernambuco, Northeast Region, Brazil, } 2002 \text { until } \\
2005 .\end{array}$ & $\begin{array}{l}\text { Padilha et al., 2005. DENTAL Planning in the Family } \\
\text { Health Program of the State of Paraíba: A qualitative } \\
\text { study }\end{array}$ \\
\hline $\begin{array}{l}\text { Busato et al., 2011. Evaluation of the perception of the } \\
\text { oral health teams of the municipal health department } \\
\text { of Curitiba, Paraná State, regarding atraumatic } \\
\text { restorative treatment (ART). }\end{array}$ & $\begin{array}{l}\text { Neto et al., 2007. Restaurações diretas na ESF em } \\
\text { Teresina. Direct restorations in the family health } \\
\text { program in Teresina (PI). }\end{array}$ \\
\hline $\begin{array}{l}\text { Pimentel et al., 2010. Analysis of oral health attention } \\
\text { in the Family Health Strategy of the Sanitary District } \\
\text { VI, Recife, Pernambuco State. }\end{array}$ & $\begin{array}{l}\text { Moura et al., 2010. Profile and procedures of the } \\
\text { community health agents regarding oral health in the } \\
\text { countryside of Piauí State, Brazil. }\end{array}$ \\
\hline $\begin{array}{l}\text { Lima et al., 2006. Early oral health care : family health } \\
\text { team task. }\end{array}$ & $\begin{array}{l}\text { Santos; Assis, 2005. Relation net of buccal health } \\
\text { practice's protagonist in the family health program in } \\
\text { Alagoinhas- Bahía. }\end{array}$ \\
\hline
\end{tabular}


Chart 1. Author, Publication Year. Article title.

\begin{tabular}{|c|c|}
\hline Author, Publication Year. Article title & Author, Publication Year. Article title. \\
\hline $\begin{array}{l}\text { Faccin et al., 2010. Work process in oral health: seeking } \\
\text { different looks to understand and transform the } \\
\text { reality. }\end{array}$ & $\begin{array}{l}\text { Fonseca et al., 2013. The oral health of seniors in } \\
\text { Brazil: addressing the consequences of a historic lack } \\
\text { of public health dentistry in an unequal society. }\end{array}$ \\
\hline $\begin{array}{l}\text { Moretti et al., 2010. Intersectoriality in health } \\
\text { promotion actions carried out by the oral health team } \\
\text { of Curitiba, Paraná State. }\end{array}$ & $\begin{array}{l}\text { Silva; Gomes Filho, 2012. Perception of the users } \\
\text { about the incorporation of the oral health team in the } \\
\text { Family Health Program. }\end{array}$ \\
\hline $\begin{array}{l}\text { Martelli et al., 2010. Surgeon dentist's profile inserted } \\
\text { in the Strategy of Family Health in cities in the state of } \\
\text { Pernambuco, Brazil. }\end{array}$ & $\begin{array}{l}\text { Correia; Silveira, 2011. Perception Regarding the Oral } \\
\text { Health and Premature Birth among Members of Staff } \\
\text { of FHS and Pregnant women. }\end{array}$ \\
\hline $\begin{array}{l}\text { Rodrigues et al., 2010. Health community agent: } \\
\text { subject of the buccal health practice in Alagoinhas, } \\
\text { Bahia state. }\end{array}$ & $\begin{array}{l}\text { Tonello et al., 2007. Assessment of oral health status } \\
\text { of pregnant women participating in a family health } \\
\text { program in the city of Lucas do Rio Verde - MT - } \\
\text { Brazil }\end{array}$ \\
\hline $\begin{array}{l}\text { Pereira et al., 2009. Inclusion of oral health teams in } \\
\text { the Family Health Program and its impact on the use } \\
\text { of dental services. }\end{array}$ & $\begin{array}{l}\text { Godoi et al., 2014. An oral health care network } \\
\text { organized by large municipalities in Santa Catarina } \\
\text { State, Brazil. }\end{array}$ \\
\hline $\begin{array}{l}\text { Frazão; Marques, 2009. Effectiveness of a community } \\
\text { health worker program on oral health promotion. }\end{array}$ & $\begin{array}{l}\text { Moura et al., 2013. Oral health in the family health } \\
\text { strategy in a regional management territory of the } \\
\text { state of Piaui. }\end{array}$ \\
\hline $\begin{array}{l}\text { Nascimento et al., 2009. Oral health in the family } \\
\text { health strategy: a change of practices or semantics } \\
\text { diversionism. }\end{array}$ & $\begin{array}{l}\text { Palmier et al., 2012. Socioeconomic indicators and } \\
\text { oral health services in an underprivileged area of } \\
\text { Brazil. }\end{array}$ \\
\hline $\begin{array}{l}\text { Almeida et al., 2009. The dental health of preschool- } \\
\text { aged children resident in areas covered by the Family } \\
\text { Health Program, in the city of Salvador, in the State of } \\
\text { Bahia, Brazil. }\end{array}$ & $\begin{array}{l}\text { Abreu et al., 2013. A survey of the sociodemographic } \\
\text { and educational characteristics of oral health } \\
\text { technicians in public primary health care teams in } \\
\text { Minas Gerais, Brazil. }\end{array}$ \\
\hline $\begin{array}{l}\text { Lourenço et al., 2009. The insertion of oral health } \\
\text { services in the Family Health Program at Minas Gerais } \\
\text { State, Brazil. }\end{array}$ & $\begin{array}{l}\text { Matos; Tomita, 2004. Oral health in the Brazilian } \\
\text { Family Health Program: from the university to } \\
\text { training centers. }\end{array}$ \\
\hline $\begin{array}{l}\text { Holanda et al., 2009. Reflections around the } \\
\text { performance of community health agents in oral } \\
\text { health strategies. }\end{array}$ & $\begin{array}{l}\text { Colussi; Calvo, 2011. An evaluation model for oral } \\
\text { health in primary care. }\end{array}$ \\
\hline $\begin{array}{l}\text { Reis et al., 2009. Evaluation of oral health service in } \\
\text { Grão Mogol city, state of Minas Gerais, Brazil: "the } \\
\text { users' voice. }\end{array}$ & $\begin{array}{l}\text { Colussi et al., 2013. The Linear Programming to } \\
\text { evaluate the performance of Oral Health in Primary } \\
\text { Care. }\end{array}$ \\
\hline $\begin{array}{l}\text { Terreri; Soler, 2008. Comparative study of two } \\
\text { classification criteria used in the Family Health } \\
\text { Program to prioritize treatment of dental caries in } \\
\text { 5-to-12 year-old children. }\end{array}$ & $\begin{array}{l}\text { Pucca Junior et al., 2010. Financing national policy } \\
\text { on oral health in Brazil in the context of the Unified } \\
\text { Health System. }\end{array}$ \\
\hline $\begin{array}{l}\text { Rocha; Goes, 2008. Comparison of access to Oral } \\
\text { Health Services between areas covered and not covered } \\
\text { by the Family Health Program in Campina Grande, } \\
\text { Paraíba State, Brazil. }\end{array}$ & $\begin{array}{l}\text { Kusma; Moyses, 2012. Health promotion: perspectives } \\
\text { for evaluation of oral health in primary healthcare. }\end{array}$ \\
\hline $\begin{array}{l}\text { Almeida; Ferrreira, 2008. Oral health in the context } \\
\text { of the Family Health Program: preventive practices } \\
\text { targeting individual and public health. }\end{array}$ & $\begin{array}{l}\text { Lemos et al., } 2010 \text {. The oral health care model in } \\
\text { Middle and Low Xingu: partnerships, processes, and } \\
\text { perspectives. }\end{array}$ \\
\hline $\begin{array}{l}\text { Santos et al., 2008.Bond and autonomy of the oral } \\
\text { health practice in the Family Health Program. }\end{array}$ & $\begin{array}{l}\text { Martins et al., 2011. How primary health care } \\
\text { professionals and residents assess issues related to the } \\
\text { oral health of older persons? }\end{array}$ \\
\hline $\begin{array}{l}\text { Koyashiki et al., 2008. The work in oral health of the } \\
\text { Community Health Agent in Family Health Units. }\end{array}$ & $\begin{array}{l}\text { Lindoso et al., 2005. Caries active white spots and } \\
\text { dental biofilms prevalences in children from } 0 \text { to } 36 \\
\text { months of age, assisted by Family Health Program in } \\
\text { Camaragibe - PE, Brazil. }\end{array}$ \\
\hline
\end{tabular}


Chart 1. Author, Publication Year. Article title.

\begin{tabular}{|c|c|}
\hline Author, Publication Year. Article title & Author, Publication Year. Article title. \\
\hline $\begin{array}{l}\text { Martelli et al., 2008. Analysis of the oral health care } \\
\text { model in cities of the state of Pernambuco. }\end{array}$ & $\begin{array}{l}\text { Carnut et al., 2011. Initial validation of the index of } \\
\text { oral healtcare needs for oral health teams in the family } \\
\text { healthcare strategy. }\end{array}$ \\
\hline $\begin{array}{l}\text { Emmi; Barroso, 2008. Evaluation of oral health actions } \\
\text { in the Family Health Program in the Mosqueiro } \\
\text { district, Pará State, Brazil. }\end{array}$ & $\begin{array}{l}\text { Cunha et al., 2011. Oral Health in Diadema, Brazil: } \\
\text { from schoolchildren dentistry to family health } \\
\text { strategy.. }\end{array}$ \\
\hline $\begin{array}{l}\text { Souza; Roncalli, 2007. Oral health in the Brazilian } \\
\text { Family Health Program: a health care model } \\
\text { evaluation. }\end{array}$ & $\begin{array}{l}\text { Costa et al., 2010. Working Process of Dentist in the } \\
\text { Family Health Strategy of Parnamirim-RN: Facing the } \\
\text { Challenges of a New Care Model }\end{array}$ \\
\hline $\begin{array}{l}\text { Santos et al., 2007. Conflicting situations in the } \\
\text { reception of oral health teams from the Family Health } \\
\text { Program in Alagoinhas, Bahia, Brazil. }\end{array}$ & $\begin{array}{l}\text { Almeida et al., 2010. Preventive action in oral health } \\
\text { development in the Family Health Strategy: how are } \\
\text { the dentists evaluating the results in its work process? }\end{array}$ \\
\hline $\begin{array}{l}\text { Chaves; Vieira da Silva, 2007. Oral health care and } \\
\text { health decentralization in Brazil: two case studies in } \\
\text { Bahia State. }\end{array}$ & $\begin{array}{l}\text { Rodrigues et al., 2009. Dental health in feira de } \\
\text { santana (BA) family health program: the surgeon } \\
\text { dentist profile. }\end{array}$ \\
\hline $\begin{array}{l}\text { Santos; Assis, 2006. From fragmentation to integrality: } \\
\text { constructing and reconstructing the practice of buccal } \\
\text { health in the Alagoinhas (BA) Family Health Program. }\end{array}$ & $\begin{array}{l}\text { Freire, 2013. The Family Health Strategy workers' } \\
\text { perception of the oral health team performance in } \\
\text { Goiânia-GO, Brazil, 2009: a qualitative study. }\end{array}$ \\
\hline $\begin{array}{l}\text { Fakhouri, 2004. The real situation of the dentist inside } \\
\text { the family health program. }\end{array}$ & $\begin{array}{l}\text { Soares et al., 2013. Constructing public oral health } \\
\text { policies in Brazil: issues for reflection. }\end{array}$ \\
\hline $\begin{array}{l}\text { Fischer et al., 2010. Primary dental care indicators: } \\
\text { association with socioeconomic status, dental care, } \\
\text { water fluoridation and Family Health Program in } \\
\text { Southern Brazil. }\end{array}$ & $\begin{array}{l}\text { Rocha; Araujo, 2009. Working conditions of oral } \\
\text { health teams in the Family Health Program: the case } \\
\text { of North Health District in Natal, RN, Brazil. }\end{array}$ \\
\hline $\begin{array}{l}\text { Mello; Moysés, 2010. Best practices in local health } \\
\text { systems: focusing on the elderly's oral health. }\end{array}$ & $\begin{array}{l}\text { Turrioni et al., 2012. Assessment of educational } \\
\text { actions on the oral health of adolescents within the } \\
\text { Family Health Strategy. }\end{array}$ \\
\hline $\begin{array}{l}\text { Melo et al., 2012. Oral healh National Policy and } \\
\text { bioethics of protection by the integral care. }\end{array}$ & $\begin{array}{l}\text { Rodrigues et al., 2011. Oral health in family health } \\
\text { strategy in a town of the bahian semiarid. }\end{array}$ \\
\hline $\begin{array}{l}\text { Ciombra et al., 2012. Relationship between dental } \\
\text { caries risk and socioeconomic and demographic } \\
\text { variables in users of the Family Health Strategy in the } \\
\text { city of Amparo, SP: a longitudinal study. }\end{array}$ & $\begin{array}{l}\text { Castim et al., 2014. Analysis of oral health indicators } \\
\text { of Pernambuco: performance of cities according } \\
\text { to size population, population enrolled in the } \\
\text { Information System for Primary Care and proportion } \\
\text { in the Family Health Strategy. }\end{array}$ \\
\hline $\begin{array}{l}\text { Rodrigues; Assis, 2005. Supply and demand in the } \\
\text { buccal health care: the work process in the family } \\
\text { health care program in Alagoinhas - Bahia. }\end{array}$ & $\begin{array}{l}\text { Baldani et al., 2005. Inclusion of oral health services } \\
\text { in the Family Health Program in the State of Paraná, } \\
\text { Brazil. }\end{array}$ \\
\hline $\begin{array}{l}\text { Almeida et al., 2012. Family context, malocclusion } \\
\text { and oral habits in preschool children living in areas } \\
\text { assisted by Family Health Strategy, Salvador, State of } \\
\text { Bahia, Brazil. }\end{array}$ & $\begin{array}{l}\text { Padula, 2014. Professional profile of dentists who are } \\
\text { members of the Family Health Strategy city of Marília, } \\
\text { São Paulo: the challenge of interprofessional work. }\end{array}$ \\
\hline $\begin{array}{l}\text { Orth et al., 2012. Tuberculosis and the oral health staff } \\
\text { in the family health program of São Carlos - SP, Brazil }\end{array}$ & $\begin{array}{l}\text { Oliveira et al., 2014. Use of dental services in areas } \\
\text { covered by the Family Health Strategy in Olinda, } \\
\text { Brazil }\end{array}$ \\
\hline $\begin{array}{l}\text { Gonçalves et al., 2012. Variables associated to the } \\
\text { performance of dental surgeons in the health family } \\
\text { strategy }\end{array}$ & $\begin{array}{l}\text { Pace et al., 2006. Oral hygiene habits of family enrolled } \\
\text { in a Family Health Program in Ribeirão Preto: SP, } \\
\text { Brazil. }\end{array}$ \\
\hline $\begin{array}{l}\text { Garbin et al., 2012. Oral health care parameters: } \\
\text { comparison between two methods of scheduling } \\
\text { clinical dental care in the public service. }\end{array}$ & $\begin{array}{l}\text { Silveira et al., 2014. The interaction of several fields of } \\
\text { knowledge for the articulation of collective oral health } \\
\text { actions: the mapping of a family health team. }\end{array}$ \\
\hline $\begin{array}{l}\text { Cavalcanti et al., 2012. Use and Access to Oral Health } \\
\text { Services of SUS - A Comparison between Rural and } \\
\text { Urban Populations. }\end{array}$ & $\begin{array}{l}\text { França et al., 2007. Therapeutic with medicinal plants } \\
\text { in the oral diseases: the perception of the professionals } \\
\text { in the program of family health of Recife. }\end{array}$ \\
\hline
\end{tabular}


Chart 1. Author, Publication Year. Article title.

\begin{tabular}{|c|c|}
\hline Author, Publication Year. Article title & Author, Publication Year. Article title. \\
\hline $\begin{array}{l}\text { Melo et al., 2012. Level of Information and Preventive } \\
\text { Behavior of Patients Attending the Family Health } \\
\text { Program of Aracaju-SE Regarding Oral Cancer. }\end{array}$ & $\begin{array}{l}\text { Mattos et al., 2014. The inclusion of the oral health } \\
\text { team in the Brazilian Family Health Strategy: barriers, } \\
\text { advances and challenges. }\end{array}$ \\
\hline $\begin{array}{l}\text { Lopes Júnior et al., 2010. The oral health in the Family } \\
\text { Health Strategy: a methodological interface based on } \\
\text { Delphi technique. }\end{array}$ & $\begin{array}{l}\text { Sanglard-Oliveira et al., 2013. Responsibilities of } \\
\text { oral health technician in the family health strategy in } \\
\text { Minas Gerais, Brazil. }\end{array}$ \\
\hline $\begin{array}{l}\text { Aragão et al., 2012. Accessibility of Disabled Children } \\
\text { and Adolescents to Basic Oral Health Attention at the } \\
\text { Public Health system - A Pilot Study. }\end{array}$ & $\begin{array}{l}\text { Mialhe et al., 2011. Community health agents and } \\
\text { their educational practices in oral health: a qualitative/ } \\
\text { quantitative evaluation. }\end{array}$ \\
\hline $\begin{array}{l}\text { Da Silva et al., 2010. Prevalence of the periodontal } \\
\text { disease in women and children from the Family } \\
\text { Health Strategy in Campo Grande city-MS. }\end{array}$ & $\begin{array}{l}\text { Anacleto; Cutolo, 2007. Contributions for a discussion } \\
\text { about the odontologycs formation, beginning from } \\
\text { the inclusion of the oral health in the Family's Health } \\
\text { Strategies: [review]. }\end{array}$ \\
\hline $\begin{array}{l}\text { Carneiro et al., 2012. Occurrence of Tooth Loss } \\
\text { Among Users of the Family Health Strategy in } \\
\text { Campina Grande - PB. }\end{array}$ & $\begin{array}{l}\text { Agripino et al., 2007. Dentistry and the Family Health } \\
\text { Program: new challenges and perspectives. }\end{array}$ \\
\hline $\begin{array}{l}\text { Alves et al., 2012. Service-Learning Integration } \\
\text { Process: Successful Experience in Providing Oral Care } \\
\text { to the Community }\end{array}$ & $\begin{array}{l}\text { Oliveira et al., 2009. Oral health in the family health } \\
\text { strategy: perceptions of professionals and family } \\
\text { carers. }\end{array}$ \\
\hline $\begin{array}{l}\text { Szpilman; Oliveira, 2011. The user's perception on the } \\
\text { dentistry health services in health unities in Vila Velha } \\
\text { (ES), Brazil. }\end{array}$ & $\begin{array}{l}\text { Cavalcanti et al., 2012. Evaluation of users of basic } \\
\text { attention healthcare about the implantation of an } \\
\text { integral dental assistance protocol. }\end{array}$ \\
\hline $\begin{array}{l}\text { Martello et al., 2012. Dental caries and factors } \\
\text { associated in children aged three years enrolled } \\
\text { in Family Health Units in the Municipality of } \\
\text { Rondonopolis, Mato Grosso, Brazil. }\end{array}$ & $\begin{array}{l}\text { Macedo et al., 2008. Evaluation of the surgeon-dentists } \\
\text { placed in the Family Health Strategy of the cityof } \\
\text { Recife as for how appropriate is their knowledge } \\
\text { concerned the actions in thisstrategy. }\end{array}$ \\
\hline $\begin{array}{l}\text { Rodrigues; Bomfim, 2010. Oral health in the family } \\
\text { health program of a municipality of the semi-arid } \\
\text { region of Bahia (Feira de Santana): organization and } \\
\text { micropolitics. }\end{array}$ & $\begin{array}{l}\text { Silva et al., 2011. Study on oral health of elderly } \\
\text { patients linked to a Family Health Program, who take } \\
\text { antihypertensive medication }\end{array}$ \\
\hline $\begin{array}{l}\text { Marin; Leite, 2011. Prevalence of dental caries in } \\
\text { 5-6-year-old schoolchildren assisted by the family } \\
\text { health program in a medium-sized city of Minas } \\
\text { Gerais - Brazil. }\end{array}$ & \multirow[t]{2}{*}{$\begin{array}{l}\text { Farias; Sampaio, 2011. Role of the dental surgeon in } \\
\text { the family health team. }\end{array}$} \\
\hline $\begin{array}{l}\text { Anjos et al., 2011. Brazilian oral health crew: advances } \\
\text { and challenges. }\end{array}$ & \\
\hline
\end{tabular}

Fifteen thematic categories were identified in the 141 selected articles (Table 1). The most discussed thematic category in the analysed production was the implementation process of oral health teams in the FHS follow by teamwork process. The highest number of publications was found in 2010 with 26 articles focused on the review topic. The distribution of articles according to publication year is presented in Figure 2. The majority of the articles were published in national journals; only five were published in international journals. The journal with the largest number of published articles was 'Ciência e
Saúde Coletiva' $(\mathrm{n}=28$ ) in the period between 2004 and 2014. The majority of the articles were published by authors from public universities ( $\mathrm{n}$ $=114$ ). Only eighteen articles had professionals working in primary care teams participating as authors.

The region in which the largest number of published articles originated was the Northeast $(n=61)$, followed by the Southeast $(n=37)$ and the South $(\mathrm{n}=22)$. The regions with the lowest number of publications were the North $(\mathrm{n}=2)$ and Mid-west $(\mathrm{n}=5)$. Of the 141 articles, three were nationally based studies, and 11 were lit- 
erature reviews on the topic, not representing any region. The categorization of the studies by Brazilian states is shown in Figure 3. Two articles presented information regarding only the region where they were conducted, not the state. As for the research method used, $42 \%$ were qualitative

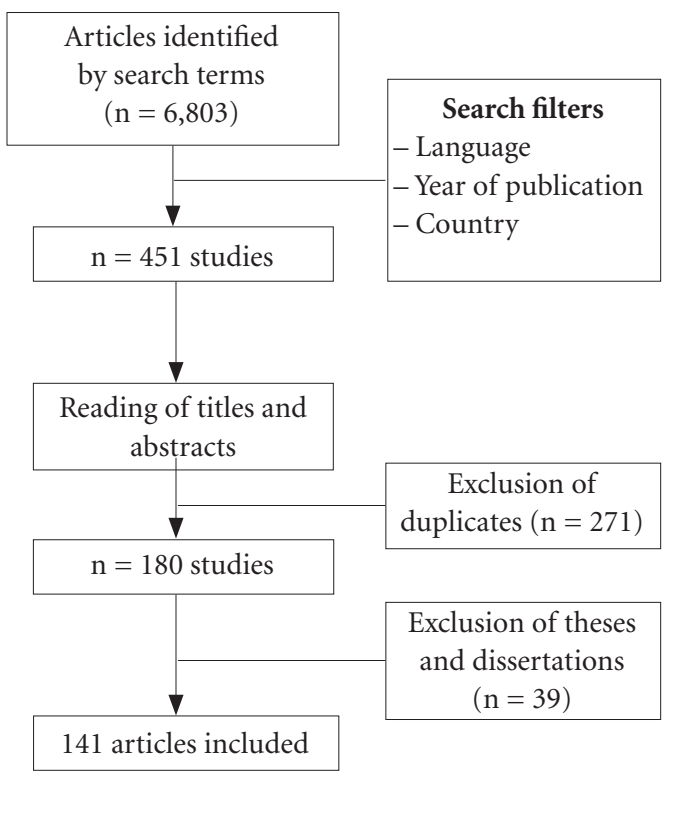

Figure 1. Flow diagram of selection of articles. $(\mathrm{n}=59), 57 \%$ quantitative $(\mathrm{n}=80)$, and $1 \%$ qualitative and quantitative $(\mathrm{n}=2)$.

There was recently an increasing interest in investigating the context of oral health implementation in the FHS. Thus the years 2010, 2011 and 2012 had the highest number of publications, with the sum of articles published in that period being higher than the sum of publications in other years in the evaluated period and the majority of the authors are affiliated with public universities.

\section{Discussion}

The first finding is that there was recently an increasing interest in investigating the context of oral health implementation in the FHS. This investigative movement is most likely correlated with the more than a decade already spent in national trials with this type of care. In other words, the increasing national experience on the subject likely led to a deeper scrutiny and appreciation of its capabilities and limitations, justifying the greater frequency of publications in the years 2010, 2011 and 2012.

Three Brazilian regions originated the largest number of published articles (Northeast, Southeast and the South) and this distribution of the articles is characterized by geographical inequalities. Perhaps this can be justified by the local experience on the subject and distribution of dentists in Brazil, varies greatly by region ${ }^{11}$.

Table 1. Absolute and relative frequency of articles on oral health in the Family Health Strategy (FHS), according to the topic covered, Brazil, 2004-2014.

\begin{tabular}{lr}
\hline \multicolumn{1}{c}{ Thematic Variables } & No (\%) \\
\hline Oral health status of the assisted population & $15(10.6)$ \\
Impact of actions on indicators/Analysis of indicators & $8(5.7)$ \\
Performance of the oral health assistant/oral health technician & $5(3.6)$ \\
Team work process & $17(12.0)$ \\
Procedures performed by the team/Actions of oral health education & $6(4.3)$ \\
Full attention to the user/Integrality & $2(1.4)$ \\
Actions and oral health knowledge of the community worker & $6(4.3)$ \\
Surgeon profile - dentist engaged in FHS & $12(8.5)$ \\
Organization/reorganization of public dental services & $10(7.0)$ \\
Implementation process of oral health teams in the FHS & $18(12.8)$ \\
Intersectionality of the actions developed & $3(2.0)$ \\
Access to services/Inequities in access & $13(9.2)$ \\
Perception of the user regarding the service or own health & $14(10.0)$ \\
Perception of the professionals regarding the FHS and its performance & $5(3.6)$ \\
Progress and challenges of oral health teams in the FHS & $7(5)$ \\
& Total = 141
\end{tabular}




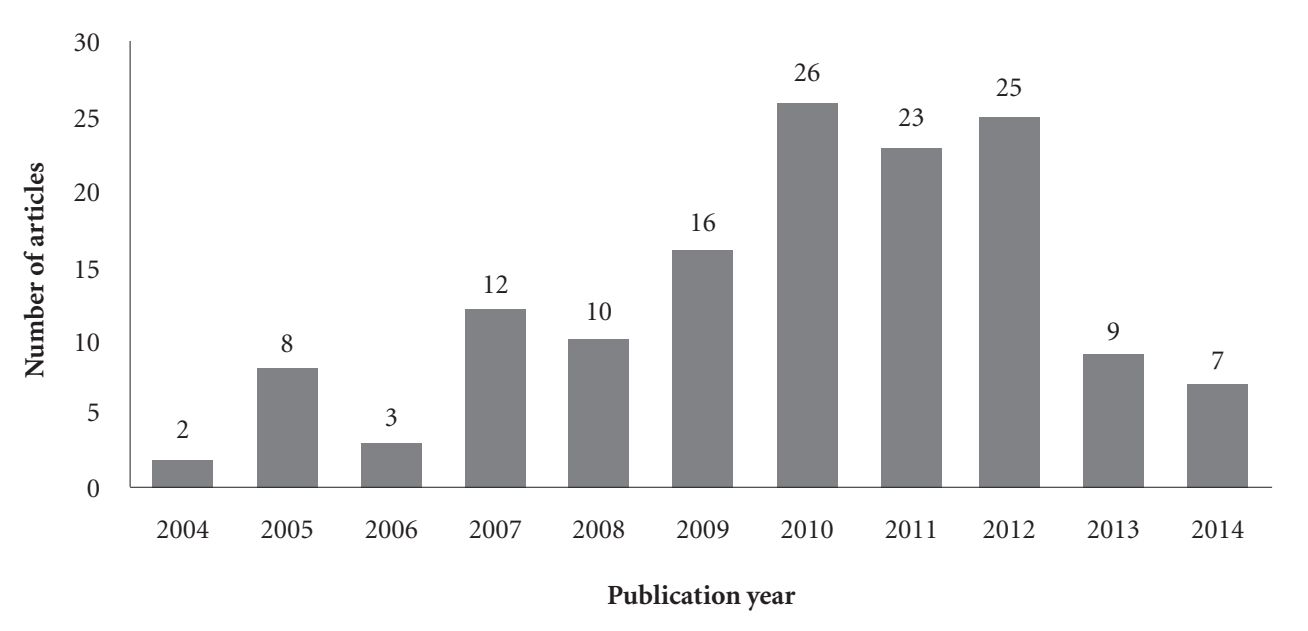

Figure 2. Number of articles on oral health in the Family Health Strategy published in the period between 2004 and 2014.

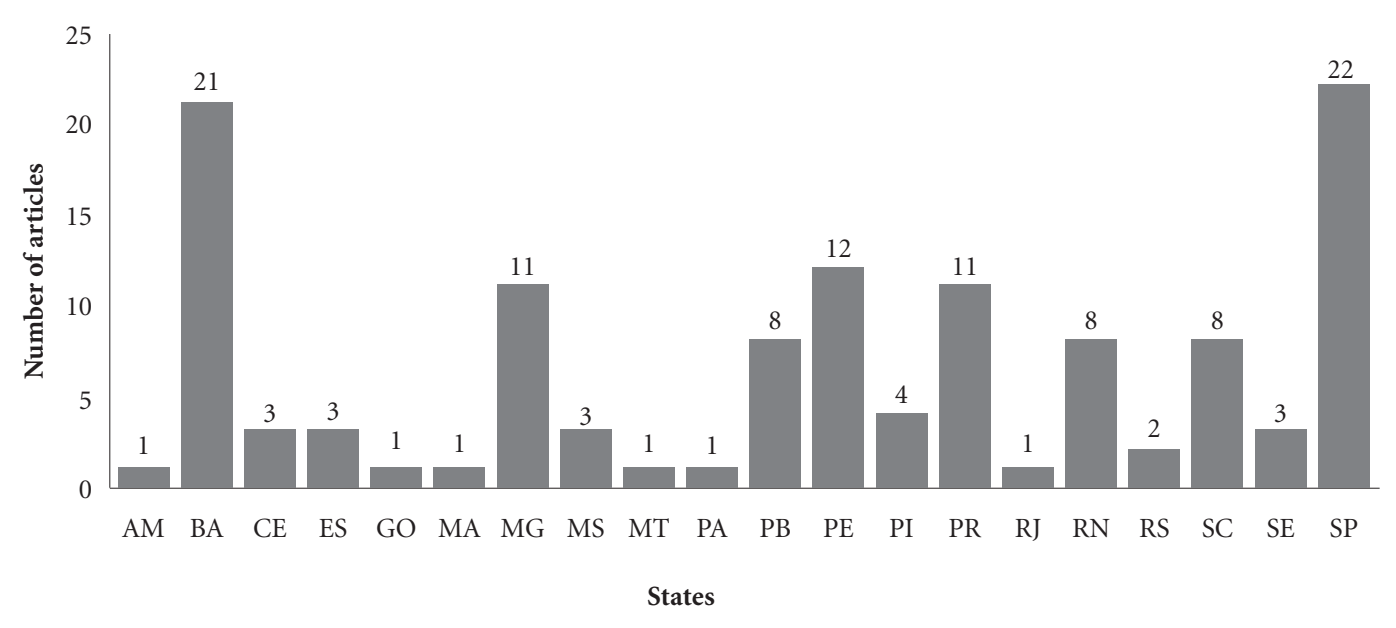

Figure 3. Distribution of the Brazilian states by number of articles on oral health in the Family Health Strategy published in the period between 2004 and 2014.

Analysis of the publications showed that the majority of the authors are affiliated with public universities; fewer professionals working in primary care teams participated as authors. The inclusion of professionals from the OHT/FHS as authors and not only as participants in the research is something to be considered in future studies as it would promote greater knowledge ownership in the scenarios studied, avoiding unilaterality of the knowledge produced ${ }^{12,13}$ in addi- tion to stimulating the integration of education and health services (one of the guidelines for the paradigm shift in terms of professional training in health).

The second most discussed thematic category in the analysed production was the micro-process work of OHT/FHS. Perhaps this can be justified by the difficulties that teams still find in the practices recommended by the National Oral Health Policy in addition to the challenge 
of breaking with a working process marked since its formation by a clinical focused fragmenta$\operatorname{tion}^{13-15}$, suggesting the adoption of a model for comprehensive care centred on the families and people's needs ${ }^{1,16,17}$.

Despite these difficulties, there are initiatives of professional oral health practices based on health education ${ }^{17,18}$ and health promotion ${ }^{19-21}$. These produce improvements in health conditions and practices (20-22) as they are effective in reducing the weaknesses of specific groups and health inequity ${ }^{22}$, despite reduced intersectoriality ${ }^{21-28}$.

Another important theme evaluated was the insertion of OHT into the FHS, certainly a contentious process for most professionals as it involves the dynamic of the encounter between two not well resolved dimensions of a dentist's identity: academic training often focused on individual action and work in a multidisciplinary team of which he/she must be a part ${ }^{14,22,29,30}$. Studies show that these professionals are forced to reconstruct their identities, a paradoxical process marked by difficulties in breaking paradigms and incorporation of new practices ${ }^{31}$. In this sense, it is worth remembering that the OHT were inserted late in the FHS when compared to medical professionals and nurses ${ }^{2,4}$.

According to Chaves ${ }^{32}$, many dentists who work with the FHS experience this professional identity crisis determined by the conflicts generated by the need to rebuild their corporate identity and markedly influenced by the dentistry market and the challenging environment of the public space to be built in oral health services in the country. Real work experiences in Brazilian social spaces should be the starting point for the search of theoretical frameworks in academic training; this could be obtained if students were encouraged following graduation to take responsibility and perform caring interventions that overcome the fragmentation of professional acts, providing a critical exercise of the dimensions involved in public health work ${ }^{33}$.

From this perspective, it is noteworthy that dentists represent a contradiction between the initial perspectives related to the profession and the reality of the $\mathrm{FHS}^{34}$, which may result from professional training that did not favour the SUS, implying an inadequate profile ${ }^{35-37}$ and justifying the need for permanent health education (oral) for both dentists ${ }^{30,35-38}$ and community health agents $s^{39,40}$.

Understanding the complex relationships in health requires the use of qualitative and quan- titative methods ${ }^{41}$. In the present study, despite identification of a higher number of quantitative studies, an increased interest and performance of qualitative research was found in addition to an increase in the space for their publication in biomedical journals. Some studies call themselves qualitative-quantitative, while to Turato ${ }^{42}$ the epistemological constructions disallow this terminology; in most cases, these studies are quantitative, because the mere inclusion of literal quotations from the participants without use of coherent interpretive epistemology does not automatically legitimize the study as qualitative for the simple methodological allusion.

In this regard, we must stimulate critical reading of the literature, given that some fundamental misconceptions can be committed with the pretext of obtaining a publication, skewing results or making them at least biased ${ }^{5,7}$. As an example, in some studies equity of access to oral health services was evaluated through questionnaires and interviews with users. It is known that, to obtain more accurate information, the design of future studies should allow a direct approach to the access of services, which can be made possible through the inclusion of conceptual distinctions and of validated access/accessibility/utilization indicators. Equity of access to oral health services is not consolidated by the implementation of the OHT/FHS; it requires studies to establish the real expansion of access to/accessibility of services by different groups and the differential use of public resources ${ }^{43}$.

In any case, the impact of OHT/FHS's expansion in the growth (at least potential) of access to services and the corresponding impact on oral health conditions are important thematic categories, because they refer to the possibility of effective change in reality. However, these categories were addressed by reports of user satisfaction and analysis of clinical indicators (OHT productivity), thus limiting aspects, considering that impact studies would be more effective in assessing the effects of the strategy on the population ${ }^{4}$, which could be obtained based on other study designs and with the use of distinct indicators of epidemiological basis.

Regarding users, the majority seeking oral health services in the FHS is still women whose main motive is pain, a reflection of the high prevalence of dental cavities ${ }^{45}$, and they have reported being satisfied with the performance of the oral health team ${ }^{36,46}$.

Of the selected studies, we found only three of national basis ${ }^{47-49}$ and two at the macro-regional 
level ${ }^{49,50}$ showing the need for broad and specific research in this direction, especially when considering the size of Brazil and, therefore, its important contextual differences regarding population needs and the profile of the working process of the OHT/FHS in the various scenarios.

Studies indicate that FHS has positively impacted some health indicators in general terms $s^{43,46,47}$. However, the impact of the integration of OHT into the FHS on oral health indicators at the local and national levels is not yet defined. From this perspective, we point out that only one of the selected studies addressed this issue on a national level, in the so-called Family Health Program ${ }^{29}$.

Regarding access to dental care, it is observed that study results conflict, revealing that, while the current model of dental care has improved the access ${ }^{30,36,51,52}$, this is still considered an obstacle to overcome ${ }^{51,53}$. Some weaknesses of the care model were listed such as the limited universal access $^{50}$, integrity of actions $s^{54}$, lack of epidemiological basis of the OHT work and of monitoring/actions evaluation ${ }^{24,55}$, and limitations in the reference and counter-reference process ${ }^{24,36,38,55}$.

Such paradoxes and limitations can be explained by the inconclusive nature of the reorganization of oral health care ${ }^{5,57}$ and by the places where the studies were conducted (Brazilian states and municipalities), considering the continental dimensions of Brazil, certainly a reflection of what the cultural diversity and social determinants of health produce in the oral health-disease process.

It is possible that the inclusion of only published studies and only electronic search in this review may be a limitation as it could have excluded many studies. Despite of these limitation, with a critical analysis of the publications included in this study, it is shown that there are still thematic categories poorly explored by the published sci- entific literature, such as aspects related to financing/investment in oral health and its relationship with social inequities or in-depth analysis of the real impact of OHT/FHS actions on oral health indicators. Considering the thematic categories poorly explored, the lack of validated indicators to assess the efficacy of health care practice accurately could be a limitation faced by researcher, as well as the implementation process of public oral health policies in Brazil is not well-established, due to the later incorporation of Oral Health Teams into the Family Health Strategy and the issues of resource allocation, costs, and financing that still need to be overcomed ${ }^{58}$.

Future research should also look more deeply into the issue of the quality of the articles published with the aim of clarifying which research designs can provide the most valid and useful answer to the institutional and evaluative needs of oral health care in FHS.

\section{Conclusion}

It was concluded that, in the national scientific production, there has been a growing importance of the analysis of OHT performance inserted in the FHS. Future studies should not only include FHS workers in the authorship but also perform more conceptually in-depth approaches and with robust methodologies and analysis (multivariate analysis, multilevel logistic regression, analysis by triangulation of methods, mix methods), appreciating thematic categories such as the impact of OHT inclusion on the expansion/equity of access and use of services as well as the specific indicators of oral health conditions. For this, one must invest in differentiated methodologies that are sensitive to the proposed topic and that bring reliable subsides for planning/re-orientation of the OHT/FHS actions.

\section{Collaboration}

CE Dalazen was responsible for searching the bases data analysis, data interpretation and interpretation of the manuscript; AD De-Carli and SJ Moyses were responsible for the conception of the research, interpretation data and critical review of the final manuscript. 


\section{Referências}

1. Pimentel FC, Albuquerque PC, Martelli PJL Souza WV, Acioli RML. Caracterização do processo de trabalho das equipes de saúde bucal em municípios de Pernambuco, Brasil, segundo porte populacional: da articulação comunitária à organização do atendimento clínico. Cad Saude Publica 2012; 28(Supl.):S146-S157.

2. Faccin D, Sebold R, Carcereri DL. Processo de trabalho em saúde bucal: em busca de diferentes olhares para compreender e transformar a realidade. Cien Saude Colet 2010, 15(Supl. 1):1643-1652.

3. Almeida TF, Cangussu MCT, Chaves SCL, Silva DIC, Santos SC. Condições de saúde bucal de crianças na faixa etária pré-escolar, residentes em áreas de abrangência do Programa Saúde da Família em Salvador, Bahia, Brasil. Rev. Bras. Saúde Mater. Infant. 2009; 9(3):247252.

4. Soares FF, Figueiredo CRV, Borges NCM, Jordão RA, Freire MCM. Atuação da equipe de saúde bucal na estratégia saúde da família: análise dos estudos publicados no período 2001-2008. Cien Saude Colet 2011; 16(7):3169-3180.

5. Souza MT, Silva MD, Carvalho R. Integrative review: what is it? How to do it? Einstein 2010; 8(1):102-106.

6. Soares FF, Figueiredo CRV, Borges NCM, Jordão RA, Freire MCM. Perfil da publicação científica sobre a saúde bucal na estratégia saúde da família no período 2001-2007. RBSP 2012; 36(1):238-250.

7. Nascimento AC, Moysés ST, Werneck RI, Moysés SJ. Oral health in the context of primary care in Brazil. Int. Dent. J 2013; 63(5):237-243.

8. Mendes KDS, Silveira RCCP, Galvão CM. Revisão Integrativa: Método de pesquisa para a incorporação de evidências na saúde e na enfermagem. Texto Contexto Enferm. 2008; 17(4):758-764.

9. Leles CR, Rocha SS, Simões PA, Compagnoni MA. Taxa de publicação, na forma de artigos completos, de resumos apresentados em evento científico de pesquisa odontológica 2006. Rev. de Odontol. Unesp 2006; 35(3):141-147.

10. Whittemore R, Knafl K. The integrative review: updated methodology. J Adv Nurs 2005; 52(5):546-553.

11. Saliba NA, Moimaz SAS, Garbin CAS, Diniz DG. Dentistry in Brazil: its history and current trends. J Dent Educ 2009; 73(2):225-231.

12. Almeida GCM, Ferreira MAF. Saúde bucal no contexto do Programa Saúde da Família: práticas de prevenção orientadas ao indivíduo e ao coletivo. Cad Saude Publica 2008; 24(9):2131-2140.

13. Rocha RACP, Goes PSA. Comparação do acesso aos serviços de saúde bucal em áreas cobertas e não cobertas pela Estratégia Saúde da Família em Campina Grande, Paraíba, Brasil. Cad Saude Publica 2008; 24(12):2871-2880.

14. Farias MR, Sampaio JJC. Papel do cirurgião-dentista na equipe de saúde da família. Rev. Gaúcha Odontol. 2011; 59(1):109-115.

15. Gonçalves VB, Guerra LM, Pereira AC, Meneghim MC, Mialhe FL. Variáveis associadas ao desempenho de cirurgiões-dentistas na Estratégia de Saúde da família. RFO 2012; 17(2):201-207.

16. Santos AM, Assis MM. Da fragmentação à integralidade: construindo e (des)construindo a prática de saúde bucal no Programa de Saúde da Família (PSF) de Alagoinhas, BA. Cien Saude Colet 2006; 11(1):53-61.
17. Rodrigues AAAO, Assis MMA. Oferta e demanda na atenção à saúde bucal: o processo de trabalho no Programa Saúde da Família em Alagoinhas-BA. RBSP 2005; 29(2):273-285.

18. Turrioni APS, Salomão FGD, Monti JFC, Vazquez FL, Cortellazzi KL, Pereira AC. Avaliação das ações de educação na saúde bucal de adolescentes dentro da Estratégia de Saúde da Família. Cien Saude Colet 2012; 17(7):1841-1848.

19. Martelli PJL, Macedo CLSV, Medeiros KR, Silva SF, Cabral APS, Pimentel FC, Monteiro IS. Perfil do cirurgião-dentista inserido na Estratégia de Saúde da Família em municípios do estado de Pernambuco, Brasil. Cien Saude Colet 2010; 15(Supl. 2):3243-3248.

20. Mello, ALSF, Moysés SJ. Melhores práticas em sistemas locais de saúde: sob foco, a saúde bucal do idoso. Physis 2010; 20(3):785-809.

21. Moretti AC, Teixeira FF, Bortoloso FM, Suss FMB, Lawder JAC, Lima LSM, Bueno RE, Moysés SJ, Moysés ST. Intersetorialidade nas ações de promoção de saúde realizadas pelas equipes de saúde bucal de Curitiba (PR). Cien Saude Colet 2010, 15(Supl. 1):1827-1834.

22. Frazão P, Marques D. Effectiveness of a community health worker program on oral health promotion. Rev Saude Publica 2009; 43(3):463-471.

23. Kusma SZ, Moysés ST, Moysés SJ. Promoção da saúde: perspectivas avaliativas para a saúde bucal na atenção primária em saúde. Cad Saude Publica 2012; 28(Supl.):s9-s19.

24. Souza TMS, Roncalli AG. Saúde bucal no Programa Saúde da Família: uma avaliação do modelo assistencial. Cad Saude Publica 2007; 23:2727-2739.

25. Nuto SAS, Oliveira GC, Andrade JV, Maia MCG. O acolhimento em saúde bucal na Estratégia de Saúde da Família, Fortaleza-CE: Um relato de experiência. Revista APS 2010; 13(4):505-509.

26. Garbin AJI, Garbin AS, Moimaz SAS, Rovida TAS, Diniz DG. Parâmetros assistenciais em saúde bucal: comparação entre duas programações do atendimento clínico no serviço público. Rev. bras. promoç. Saúde 2012; 25(3):255-260.

27. Santos AM, Assis MMA, Nascimento MAA, Jorge MSB. Vínculo e autonomia na prática de saúde bucal no Programa Saúde da Família. Rev Saude Publica 2008; 42(3):464-470.

28. Terreri ALM, Soler ZASG. Estudo comparativo de dois critérios utilizados no Programa Saúde da Família na priorização do tratamento da cárie entre crianças de 5 a 12 anos. Cad Saude Publica 2008; 24(7):1581-1587.

29. Peixoto LSA. A dinâmica da identidade profissional em equipes multiprofissionais [dissertação]. Salvador: Universidade Federal da Bahia; 2010.

30. Lourenço EC, Silva ACB, Meneghin MC, Pereira AC. A inserção de equipes de saúde bucal no Programa Saúde da Família no Estado de Minas Gerais. Cien Saude Colet 2009; 14(Supl. 1):1367-1377.

31. Silva VO, Pinto ICM. Construção da identidade dos atores da Saúde Coletiva no Brasil: uma revisão da literatura. Interface (Botucatu) 2013; 17(46):549-560.

32. Chaves MCC. Crise de identidade profissional dos cirurgiões-dentistas que atuam no programa de saúde da família [dissertação]. Fortaleza: Universidade Federal do Ceará; 2005. 
33. Capozzolo AA, Imbrizi JM, Liberman F, Mendes R. Experience, knowledge production and health education. Interface (Botucatu) 2013; 17(45):357-370.

34. Chaves MC, Miranda AS. Discursos de cirurgiões-dentistas do Programa Saúde da Família: crise e mudança de habitus na Saúde Pública. Interface (Botucatu) 2008; 12(24):153-167.

35. Lenz TL, Rocha RO, Dotto PP, Raggio DP. Perfil dos cirurgiões-dentistas integrantes do Programa Saúde da Família em um município do Sul do Brasil. J. Health Sci. Inst. 2010; 28(2):121-124.

36. Anjos FS, Mestriner SF, Bulgarelli AF, Pinto IC, Júnior WM. Equipes de saúde bucal no brasil: avanços e desafios. Ciênc., Cuid. Saúde 2011; 10(3):601-607.

37. Villalba JP, Madureira PR, Barros NF. Perfil profissional do cirurgião-dentista para atuação no Sistema Único de Saúde (SUS). Rev. Inst. Ciênc. Saúde 2009; 27(3):262-268.

38. Baldani MH, Fadel CB, Possamai T, Queiroz MGS. A inclusão da odontologia no Programa Saúde da Família no Estado do Paraná, Brasil. Cad Saude Publica 2005; 21(4):1026-1035

39. Moura MS, Carvalho CJ, Amorim JTC, Marques MFSS, Moura LFAD, Mendes RF. Perfil e práticas de saúde bucal do agente comunitário de saúde em municípios piauienses de pequeno porte. Cien Saude Colet 2010; 15(Supl. 1):1487-1495.

40. Koyashiki GAK, Alves-Souza RA, Garanhani ML. O trabalho em saúde bucal do Agente Comunitário de Saúde em Unidades de Saúde da Família. Cien Saude Colet 2008; 13(4):1343-1354

41. Pondé MP. Estudos mistos e paradigmas em saúde. Psychiatry on line Brasil 2013; 8(2).

42. Turato ER. Métodos qualitativos e quantitativos na área da saúde: definições, diferenças e seus objetos de pesquisa. Rev Saude Publica 2005; 39(3):507-514.

43. Cavalcanti RP, Gaspar GS, Goes PSA. Utilização e Acesso aos Serviços de Saúde Bucal do SUS - Uma Comparação entre Populações Rurais e Urbanas. Pesq Bras Odontoped Clin Integr 2012; 12(1):121-126.

44. Pereira CRS, Patrício AAR, Araújo FAC, Lucena EES, Lima KC, Roncalli AG. Impacto da Estratégia Saúde da Família com equipe de saúde bucal sobre a utilização de serviços odontológicos. Cad Saude Publica 2009; 25(5):985-996.

45. Pinto EC, Barros VEJA, Coelho MQ, Costa SM. Urgências odontológicas em uma Unidade de Saúde vinculada à Estratégia Saúde da Família de Montes Claros, Minas Gerais. Arq. Odontol. 2012; 48(3):166-174.

46. Emmi DT, Barroso RFF. Avaliação das ações de saúde bucal no Programa Saúde da Família no distrito de Mosqueiro, Pará. Cien Saude Colet 2008; 13(1):35-41.

47. Celeste RQ, Vital JF, Junger WL, Reichenheim ME. Séries de procedimentos odontológicos realizadas nos serviços públicos brasileiros, 1994-2007. Cien Saude Colet 2011; 16(11):4523-4532.

48. Pucca Junior GA, Lucena EHG, Cawahisa PT. Financing national policy on oral health in Brazil in the context of the Unified Health System. Braz. Oral Res. 2010 24(Supl. 1):26-32.
49. Flamorion AF, Kimberly MJ, Mendes DC, Santos Neto PE, Ferreira RC, Isabela A. Pordeus IA, Martins AMEBL. The oral health of seniors in Brazil: addressing the consequences of a historic lack of public health dentistry in an unequal society. Gerodontology 2013; 14:1-10.

50. Pereira CRS, Giuseppe RA, Teixeira CMC, Augusto NLR, Rodrigues PAA, Costa LK. Impacto da Estratégia Saúde da Família sobre indicadores de saúde bucal: análise em municípios do Nordeste brasileiro com mais de 100 mil habitantes. Cad Saude Publica 2012; 28(3):449-462.

51. Nascimento AC, Moysés ST, Bisinelli JC, Moysés SJ. Oral health in the family health strategy: a change of practices or semantics diversionism. Rev Saude Publica 2009, 43(3):455-462.

52. Silva SF, Martelli PJL, Sá DA, Cabral AP, Pimentel FC, Monteiro IS, Macedo CLSV. Análise do avanço das equipes de saúde bucal inseridas na Estratégia Saúde da Família em Pernambuco, região Nordeste, Brasil, 2002 a 2005. Cien Saude Colet 2011; 16(1):211-220.

53. Baldani MH, Antunes JLF. Desigualdades no acesso e utilização de serviços odontológicos: estudo transversal em uma área atendida pela Estratégia Saúde da Família. Cad Saude Publica 2011; 27(Supl. 2):S272-S283.

54. Farias MR, Sampaio JJC. Integração da equipe de saúde bucal na estratégia saúde da família: a percepção dos profissionais. RBSP 2010; 34(4):745-757.

55. Pimentel FC, Petrônio José de Lima Martelli PJL, Araújo Junior JLC, Acioli RML, Macedo CLSV. Análise da atenção à saúde bucal na Estratégia de Saúde da Família do Distrito Sanitário VI, Recife (PE). Cien Saude Colet 2010, 15(4):2189-2196.

56. Cunha BAT, Marques RAA, Castro CGJ, Narvai PC. Saúde Bucal em Diadema: da odontologia escolar à estratégia saúde da família. Saúde Soc. 2011; 20(4):10331045.

57. Maia LS, Kornis GEM. A Reorganização da Atenção à Saúde Bucal frente aos incentivos federais: a experiência fluminense. Rev APS 2010, 13(1):84-95.

58. Soares CLM. Constructing public oral health policies in Brazil: issues for reflection. Braz Oral Res 2012; 26(Supl.):94-102.

Artigo apresentado em 20/04/2015

Aprovado em 11/01/2016

Versão final apresentada em 13/01/2016 
